\title{
Mobile Security Vehicle's based on Internet of Things
}

\author{
M. Husni ${ }^{1}$, R. V. H. Ginardi ${ }^{2}$, K. Gozali ${ }^{3}$, R. Rahman ${ }^{4}$, A. S. Indrawanti ${ }^{5}$, M. I. Senoaji ${ }^{6}$ \\ 1, 2, 3, 4, 5, 6 Faculty of Electrics, Institut Teknologi Sepuluh Nopember, Surabaya, Indonesia \\ Email: ${ }^{1}$ mhusni43@gmail.com, ${ }^{2}$ hari.ginardi@gmail.com, ${ }^{3}$ zidan.z2004@gmail.com, ${ }^{4}$ ridho13@gmail.com, \\ ${ }^{5}$ annisaaindrawanti@gmail.com, ${ }^{6}$ isasenoaji@gmail.com
}

\begin{abstract}
The purpose of this research is to design and build a mobile security vehicle's based on Internet of Things (IoT) that combines to Arduino-based microcontroller, internet networks and the needed hardware. The design is intended to monitor and control the vehicle condition and monitor the vehicle location based on IoT. This research uses the hardware and software component. The hardware uses the Arduino-based microcontroller that connects to some modules. This research uses Relay Module 2 Channel HL-525 to control the vehicle machine, GPS Module Neo-7M to get the vehicle location, SIM800L Module to connect to the internet network and ACS712 Voltage sensor to detect the voltage in the vehicle electricity. This research uses multi-platform (web application) as the component software to monitor and control the vehicle condition and its location. The result of this research is Mobile Security Vehicle's System Based on Arduino where the system can satisfy some functional needs such as can monitoring motorcycle location, controlling alarm, and motorcycle electricity to avoid theft through web application that can be used in multi-platform.
\end{abstract}

Keywords-Arduino UNO, Vehicle Security, Alarm, Internet of Things, Multi-platform, Web

\section{INTRODUCTION}

Nowadays, the human mobility is increasing to bolster their activity. the human mobility is bolstered by their vehicle. The vehicle is increasing rapidly nowadays [1]. But, there is a problem when having a vehicle. Because of its high value, the vehicle can be the target of the thieves. Based on the data from Indonesia Statistic Data Center, vehicle theft cases had been increased from 2011 until 2013. Tere were as many as 39.217 cases in 2011, 41.816 cases in 2012 and 42.508 cases in 2013 [13]. From the amount of the cases, not all cases were closed. There were some cases that cannot be closed because of the lost tracking of the stolen vehicles. This is the reason for the author to design and build a mobile security vehicle system that can monitor and control the vehicle using remote control.

Some researches has given for the vehicle security system with the vehicle tracking system. Some of them are vehicle security system using GPS module and IoT Platform [2][3][4]. The Internet of Things platform needs internet connection using GSM modules [5][6][7][8][9]. Some researchers have developed vehicle security system using biometrics [10][11][12], Biometrics data could be an image form and it needs more memory to save the data rather than in a text form. The researches mentioned has not used the control system to the vehicle yet. The control system is used to taking control the vehicle (by the system) when the vehicle is stolen by the thieves. So, we proposed the security vehicle system that combined the vehicle position tracking and vehicle controlling.

A mobile security vehicle system is based on IoT that embedding the hardware (Arduino-based) in the vehicle and control it using the mobile application. The term of "control" consist of controlling the on/off vehicle engine when the system detects the thieves, tracking the vehicle location and ringing the alarms when the vehicle is exposed to a vibration or moving around. One of the existing service in this system is "force shut down" service. When the "force shut down" service is activated by the user, the vehicle engine will be off automatically. this remote system using IoT concept, so that wherever the user is, they can control and monitor their vehicle remotely.

\section{METHOD}

\section{A. Anti-theft mechanism}

Vehicles have several core parts that are crucial. One of them is the electricity. Usually, vehicle electricity is divided into two parts, engine electricity and electrical auxiliary devices such as lights, starters and others. In designing the system, the vehicle electricity will be manipulated by the device.

The device can put the vehicle in several modes, namely normal mode and anti-theft mode. In normal mode, the vehicle's electrical activities will be used normally. However, when the vehicle is in anti-theft mode, the vehicle's electricity will be completely cut off so that the vehicle cannot be operated, and also if the vehicle is touched, the alarm will be active. In making this design, several modules will be used, namely the relay module, GPS and alarm as well as a voltage sensor to detect vehicle electrical conditions and vibrations. In addition, a Web-based application is used to monitor and control the equipment installed on the vehicle in real time.

The system has two modes namely normal mode and antitheft mode. The normal model is the normal activation engine electricity. The anti-theft mode is the turning off the vehicle's electricity so that the vehicle cannot be used. The system also has a buzzer control mode for sounding the vehicle when there is a vibration on it or the vehicle is moving around.

The system has two conditions, namely when it is stopped / parked or running. Because sometimes people/user forget to activate anti-theft mode. Turning off the vehicle's electricity directly during running will endanger the driver. For this reason, the upper limit speed of the vehicle to turn off the electricity is $20 \mathrm{Km} / \mathrm{h}$. The system is drawn as Fig. 1. 
As the flowchart description, there are four functional requirements in the system. They are, vehicle status monitoring, stopped vehicle controlling, moving vehicle controlling, and alarm activation of the certain cases of the vehicle. Here the functional requirement description as shown as TABLE I.

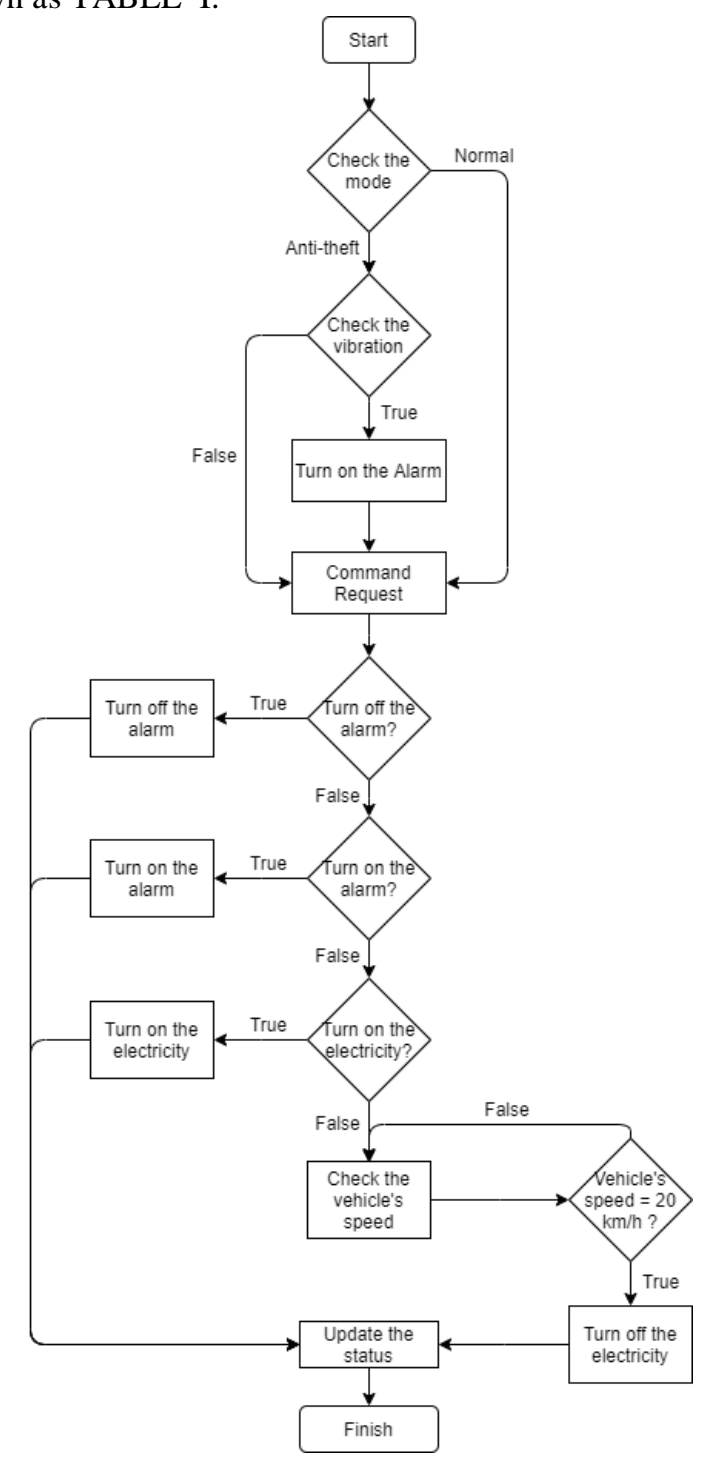

Fig. 1. The whole system flowchart

TABLE I. SYSTEM FUNCTIONAL REQUIREMENT

\begin{tabular}{|l|l|l|}
\hline code & $\begin{array}{l}\text { Functional } \\
\text { requirement }\end{array}$ & description \\
\hline F-001 & $\begin{array}{l}\text { Vehicle status } \\
\text { monitoring }\end{array}$ & $\begin{array}{l}\text { Controlling the vehicle } \\
\text { status : vehicle mode, } \\
\text { alarm and vehicle position. }\end{array}$ \\
\hline $\mathbf{F - 0 0 2}$ & $\begin{array}{l}\text { Stopped vehicle } \\
\text { controlling }\end{array}$ & $\begin{array}{l}\text { Engine mode control and } \\
\text { alarm status in stopped- } \\
\text { mode vehicle }\end{array}$ \\
\hline $\mathbf{F - 0 0 3}$ & $\begin{array}{l}\text { Running vehicle } \\
\text { controlling }\end{array}$ & $\begin{array}{l}\text { Engine mode control and } \\
\text { alarm status in running- } \\
\text { mode vehicle. }\end{array}$ \\
\hline $\mathbf{F - 0 0 4}$ & $\begin{array}{l}\text { Activated alarm in } \\
\text { anti-theft mode }\end{array}$ & $\begin{array}{l}\text { Vehicle in the anti-theft } \\
\text { mode. It means that the } \\
\text { alarm will be activated } \\
\text { when the vehicle is } \\
\text { exposed to the vibration }\end{array}$ \\
\hline
\end{tabular}

From the TABLE I above, it will be bulild up the use case code as shown TABLE II.

\section{TABLE II. USE CASE CODE EXPLANATION}

\begin{tabular}{|l|l|l|}
\hline Use case code & Use case & Actor \\
\hline UC-001 & Stopped vehicle controlling & User \\
\hline UC-002 & Running vehicle controlling & User \\
\hline UC-003 & $\begin{array}{l}\text { Vehicle status and } \\
\text { condition monitoring }\end{array}$ & User \\
\hline
\end{tabular}

The system use cloud service for monitoring and controlling the system. The system saves the data and command execution center in the cloud services. The used network architecture is as shown as Fig. 2.

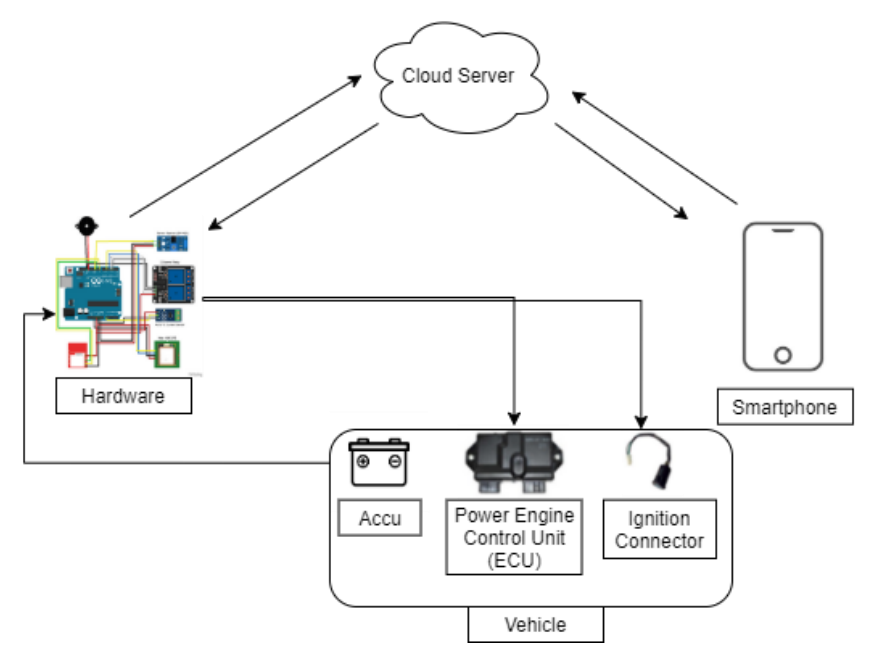

Fig. 2. The system network architecture

The system design consists of two parts, they are hardware design and web design.

- Hardware design

Hardware design is the arrangement of modules into a system that work together to produce a needed function. The used modules are the Arduino microcontroller as the control center, the SIM800L module as a connection to the internet network, the GPS module as a location detector, the Buzzer module as an alarm sound, the Relay module as a vehicle electrical system manipulation and the vibration sensor as a vehicle vibration detector when the vehicle is exposed to a vibration and the module an electric current detector to detect whether electricity is active or not. Hardware design is as shown as Fig 3.

- Web design

The web application is designed as a hardware device monitoring and controlling. The application uses the Laravel framework that will be deployed on a cPanel-based cloud. The design will consist of two pages, namely the dashboard page and the device status log page. The dashboard page contains the vehicle control center and the latest status sent by embedded device in the vehicle. Dashboard page is as shown as Fig. 4. 


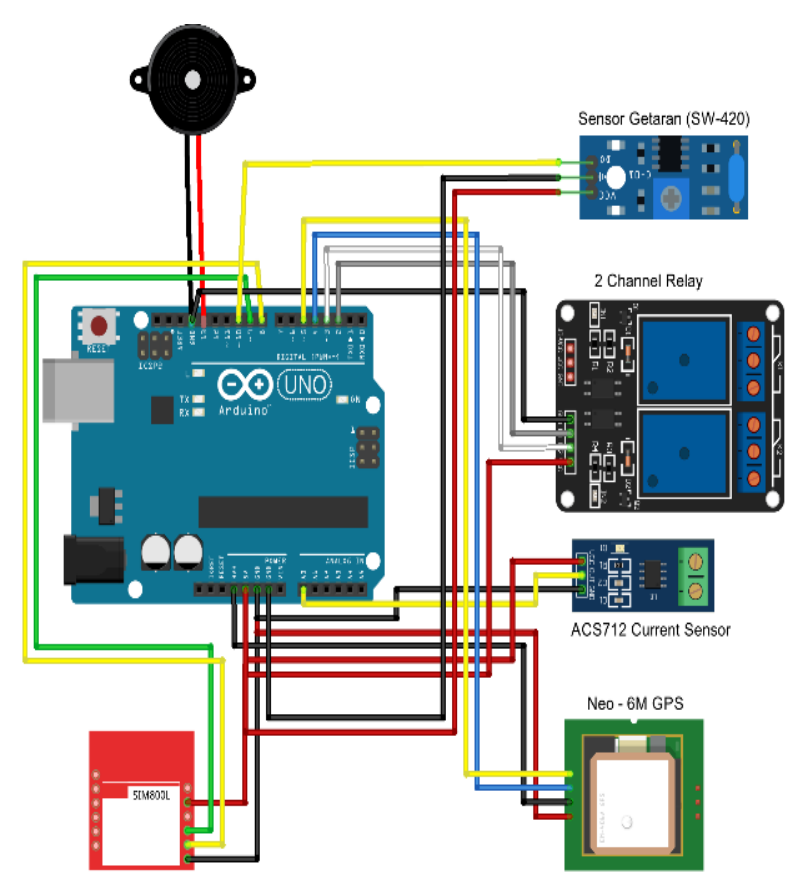

fritzing

Fig 3. Hardware design

\section{Status}
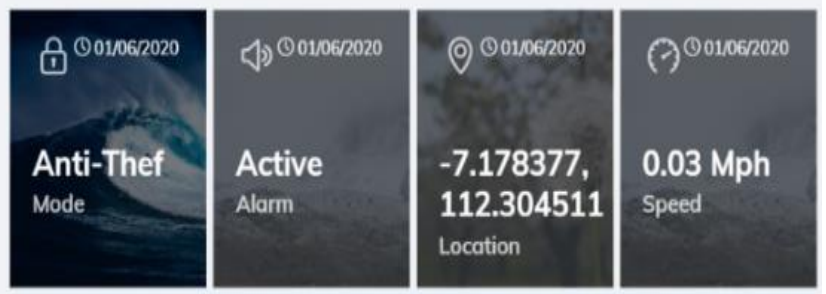

Berhosil mengubah status olarm

Management Device

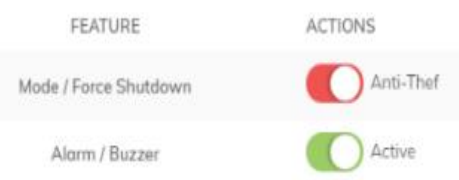

Fig. 4. Dashboard page in the web application

The device log page serves as a display of the vehicle status log data sent by the embedded device while it is active for a certain time which contains the date of delivery, vehicle mode status, alarm status, vehicle coordinates (vehicle position), vehicle speed and a button that has functions to view the position of the vehicle based on the coordinates on Google Maps. The device log page is as shown as Fig 5.

In addition, users can also view trip logs on the map according to the selected date range. The vehicle travel history will show a red line that is connected to the coordinates of the vehicle data stored in the system. The two flag images represent the start point and end point of the vehicle position based on the selected coordinate data range. The trip history of the vehicle is as shown as Fig 6 .

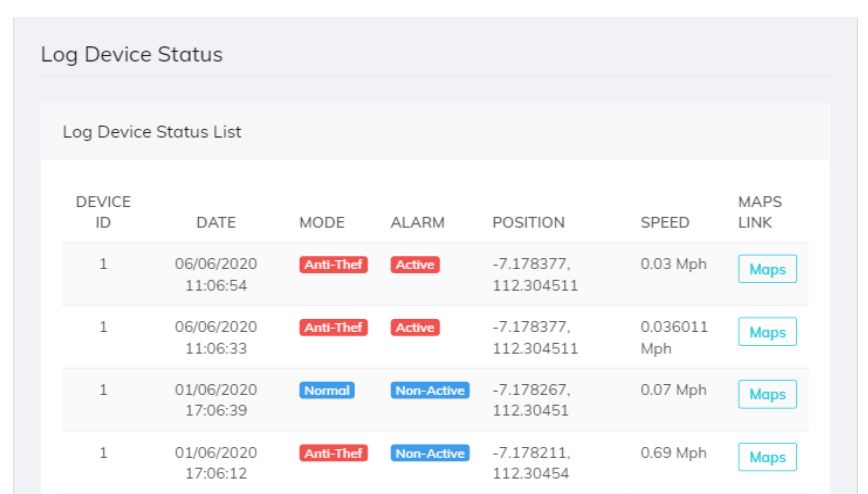

Fig 5. Device log page

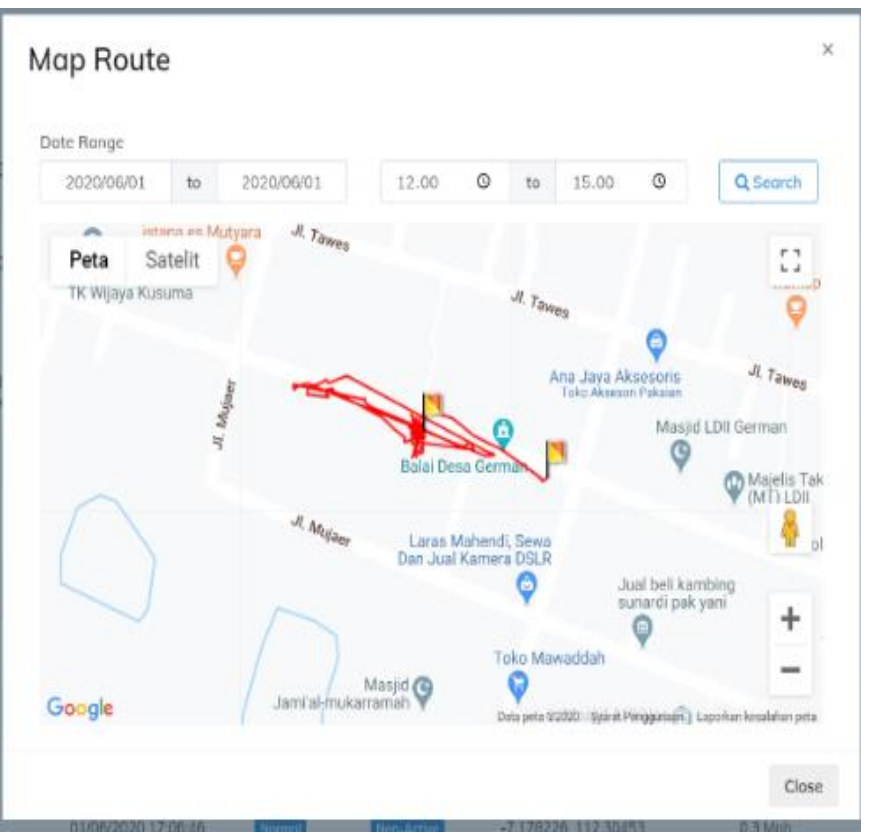

Fig 6 . The trip history page of the vehicle

\section{B. Arduino Uno}

Arduino Uno is a microcontroller based on Atmega328 (datasheet). Arduino Uno has 14 input pins 6 input pins are used as PWM output and 6 analog input pin [15][16][17]. Arduino Uno has $16 \mathrm{MHz}$ crystal oscillator, USB connection, jack power, ICSP header and reset button. To power on the microcontroller, it can be connected to the computer via USB or AC to Adaptor-DC/battery.

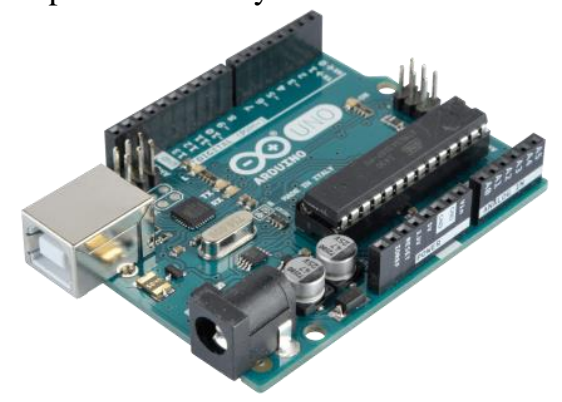

Fig 7. Arduino Uno [14]

\section{Relay Module 2 Channel HL-525}

Relay Module 2 Channel HL-525 has two relays with two kinds of level. They are level 10A @250,125 V AC and 10A 
@ 30, 28 V DC. High voltage output connector has 3 pins that consist of two pins for on/off the electricity and one pin for ready use [19][20]. On the other side, it has 2 sets of pin. The first set of pin has 1 pin for ground, 1 pin VCC and 2 input pins. The second set of pin has 3 pins with the jumper between JDVcc and VCC pin. With this configuration, electromagnetic of the relay is powered by Arduino board.

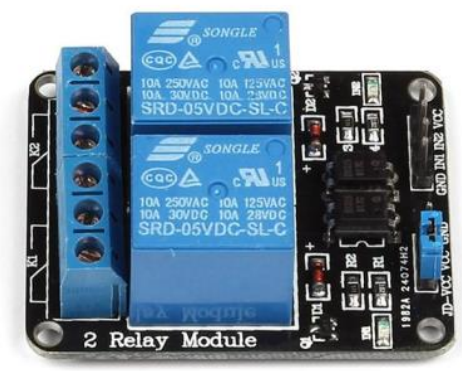

Fig 8. Relay module 2 channel HL-525 [18]

\section{GPS Module Neo-7M}

NEO-7M GPS is additional sensor to retrieve the Latitude and Longitude data or the location of the vehicle. This module needs the power of $3.3 \mathrm{v}$ and has 4 pins, they are VCC, GND, TX and RX [22][23]. In the data retrieving, the module will find the satellite and connect it. When the module has connected to the satellite, it can be known by the winking of the red LED lamp. This module uses serial communication.

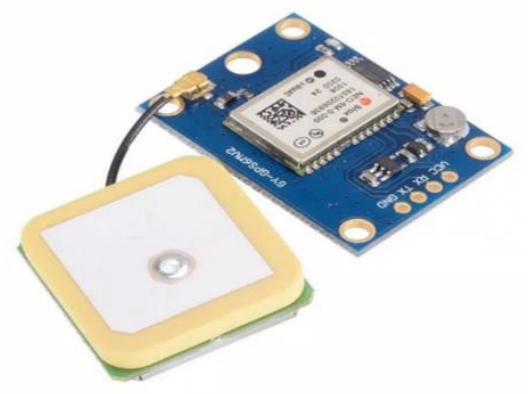

Fig 9. GPS Module Neo-7M [21]

\section{E. SIM800L Module}

SIM800L is a SIM card shield as an additional device that is used to connect the device to the network using TCP/IP connection. This module needs the power of $3.7-4.4 \mathrm{v}$ [25][26].

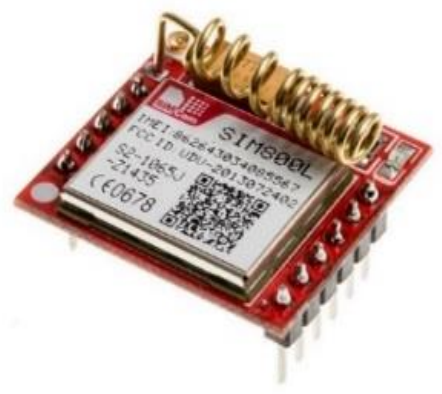

Fig 10. SIM800L Modul [24]

F. ACS-712 Voltage sensor
ACS712 is module that is used to detect the voltage in the electricity. This module can filter from the lowest voltage till the highest voltage using the analog data [28].

\section{Module Sensor ACS712}

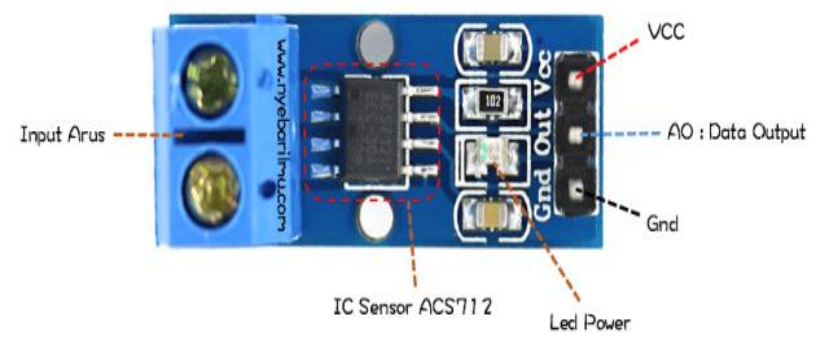

Fig 11. ACS-712 Voltage sensor [27]

\section{G. Software}

For designing the system, the authors use Star UML and for implementation, the authors use Arduino IDE to program the microcontroller [29] and Sublime Text 3 for the web application [30].

\section{RESULTS AND DISCUSSION}

The device is installed in a $150 \mathrm{cc}$ capacity motor vehicle with an injection combustion system. The electrical cable connected to the engine starter that is connected to channel 1 relay and the electrical cable connected to the power supply to the Engine Control Unit / ECU that is connected to channel 2 relay with the status of Normally Open / NO. Then on channel 2 the relay is given a jumper cable that is attached to the voltage sensor. The evaluation is exposed to the device environment explained in Table III that consists of hardware device and the software evaluation.

TABLE III. EVALUATION ENVIRONMENT

\begin{tabular}{|l|l|l|}
\hline Device & Device name & Specifications \\
\hline \multirow{5}{*}{ Hardware } & Processor & AMD Ryzen 5 3.7Ghz \\
\cline { 2 - 3 } & RAM & 4 GB \\
\cline { 2 - 3 } & System Type & 64-bit Operating System \\
\hline \multirow{2}{*}{ Software } & $\begin{array}{l}\text { Operating } \\
\text { system }\end{array}$ & CentOS with cPanel \\
\cline { 2 - 3 } & IDE & Arduino Software IDE \\
\hline
\end{tabular}

- Hardware Evaluation

Hardware evaluation is to evaluate Hardware device (Fig. 12) response to the command execution in stopped-mode and running-mode vehicle as shown in TABLE III and Table IV.

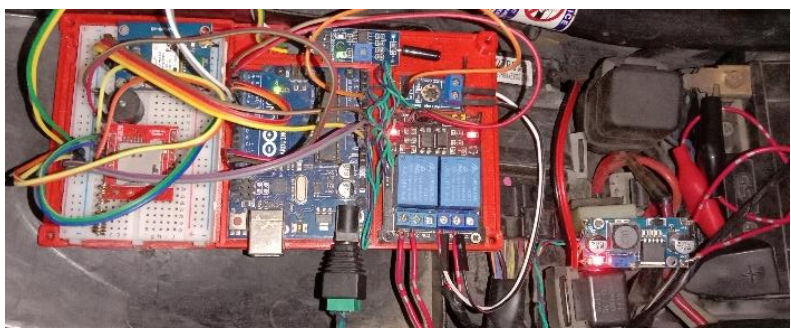

Fig 12. Hardware device 
TABLE IV. HARDWARE DEVICE RESPONSE TO THE COMMAND EXECUTION IN STOPPED-MODE VEHICLE

\begin{tabular}{|c|c|}
\hline No. & UC-001 \\
\hline $\begin{array}{l}\text { Evaluation } \\
\text { Name }\end{array}$ & $\begin{array}{l}\text { Hardware device response to the command execution } \\
\text { in stopped-mode vehicle }\end{array}$ \\
\hline $\begin{array}{l}\text { Evaluation } \\
\text { aim }\end{array}$ & $\begin{array}{l}\text { To evaluate Hardware device response to the command } \\
\text { execution in stopped-mode vehicle }\end{array}$ \\
\hline Scenario 1 & $\begin{array}{l}\text { The user activates the Anti-theft mode in the } \\
\text { application }\end{array}$ \\
\hline $\begin{array}{l}\text { Initial } \\
\text { condition }\end{array}$ & Vehicle status in the normal mode \\
\hline $\begin{array}{l}\text { Evaluation } \\
\text { steps }\end{array}$ & The user activates Anti-theft mode \\
\hline $\begin{array}{l}\text { Expected } \\
\text { results }\end{array}$ & $\begin{array}{l}\text { The vehicle status is Anti-theft mode (disconnected } \\
\text { relay) }\end{array}$ \\
\hline $\begin{array}{l}\text { Obtained } \\
\text { results }\end{array}$ & The vehicle status chages to the anti-theft mode \\
\hline $\begin{array}{l}\text { Obtained } \\
\text { result status }\end{array}$ & succeed \\
\hline $\begin{array}{l}\text { Final } \\
\text { condition }\end{array}$ & The vehicle status is Anti-theft mode \\
\hline Scenario 2 & $\begin{array}{l}\text { The user deactivates the Anti-theft mode in the } \\
\text { application }\end{array}$ \\
\hline $\begin{array}{l}\text { Initial } \\
\text { condition }\end{array}$ & Vehicle status in the Anti-theft mode \\
\hline $\begin{array}{l}\text { Evaluation } \\
\text { steps }\end{array}$ & The user deactivates Anti-theft mode \\
\hline $\begin{array}{l}\text { Expected } \\
\text { results }\end{array}$ & The vehicle status is normal mode (connected relay) \\
\hline $\begin{array}{l}\text { Obtained } \\
\text { results }\end{array}$ & The vehicle status chages to the normal mode \\
\hline $\begin{array}{l}\text { Obtained } \\
\text { result status }\end{array}$ & succeed \\
\hline $\begin{array}{l}\text { Final } \\
\text { condition }\end{array}$ & The vehicle status is normal mode \\
\hline Scenario 3 & $\begin{array}{l}\text { The alarm activation when the vehicle is exposed to } \\
\text { the vibration }\end{array}$ \\
\hline $\begin{array}{l}\text { Initial } \\
\text { condition }\end{array}$ & $\begin{array}{l}\text { The vehicle status is in Anti-theft mode and deactivated } \\
\text { alarm }\end{array}$ \\
\hline $\begin{array}{l}\text { Evaluation } \\
\text { steps }\end{array}$ & The user moving around the vehicle \\
\hline $\begin{array}{l}\text { Expected } \\
\text { results }\end{array}$ & The alarm is activated \\
\hline $\begin{array}{l}\text { Obtained } \\
\text { results }\end{array}$ & The alarm is activated \\
\hline $\begin{array}{l}\text { Obtained } \\
\text { result status }\end{array}$ & The alarm is activated \\
\hline
\end{tabular}

TABLE III. HARDWARE DEVICE RESPONSE TO THE COMMAND EXECUTION IN RUNNING-MODE

\begin{tabular}{|l|l|}
\hline No. & UC-002 \\
\hline $\begin{array}{l}\text { Evaluation } \\
\text { Name }\end{array}$ & $\begin{array}{l}\text { Hardware device response to the command execution } \\
\text { in running-mode }\end{array}$ \\
\hline $\begin{array}{l}\text { Evaluation } \\
\text { aim }\end{array}$ & $\begin{array}{l}\text { To evaluate Hardware device response to the command } \\
\text { execution in running-mode vehicle }\end{array}$ \\
\hline Scenario 1 & The user activates Anti-theft mode in the application \\
\hline $\begin{array}{l}\text { Initial } \\
\text { condition }\end{array}$ & Vehicle status in the normal mode \\
\hline $\begin{array}{l}\text { Evaluation } \\
\text { steps }\end{array}$ & The user activates the Anti-theft mode \\
\hline $\begin{array}{l}\text { Expected } \\
\text { results }\end{array}$ & The vehicle status is Anti-theft mode (disconnected relay) \\
\hline $\begin{array}{l}\text { Obtained } \\
\text { results }\end{array}$ & The vehicle status chages to the anti-theft mode \\
\hline $\begin{array}{l}\text { Final } \\
\text { condition }\end{array}$ & The vehicle status is Anti-theft mode \\
\hline
\end{tabular}

\begin{tabular}{|l|l|}
\hline $\begin{array}{l}\text { Scenario 2 } \\
\text { Initial } \\
\text { condition }\end{array}$ & $\begin{array}{l}\text { The user deactivates the Anti-theft mode in the } \\
\text { application }\end{array}$ \\
\hline $\begin{array}{l}\text { Evaluation } \\
\text { steps }\end{array}$ & The user deactivates Anti-theft mode \\
\hline $\begin{array}{l}\text { Expected } \\
\text { results }\end{array}$ & The vehicle status is normal mode (connected relay) \\
\hline $\begin{array}{l}\text { Obtained } \\
\text { results }\end{array}$ & The vehicle status chages to the normal mode \\
\hline $\begin{array}{l}\text { Final } \\
\text { Condition }\end{array}$ & The vehicle status is normal mode \\
\hline
\end{tabular}

\section{- Software Evaluation}

Software evaluation is to evaluate the success of the device in monitoring vehicle status as shown as TABLE IVI.

\section{TABLE IVI. EVALUATION THE SUCCESS OF APPLICATIONS IN} MONITORING VEHICLE STATUS

\begin{tabular}{|c|c|}
\hline No. & UC-003 \\
\hline $\begin{array}{l}\text { Evaluation } \\
\text { Name }\end{array}$ & $\begin{array}{l}\text { Evaluation the Success of Applications in Monitoring } \\
\text { Vehicle Status }\end{array}$ \\
\hline Evaluation aim & $\begin{array}{l}\text { To evaluate the success of the device in monitoring } \\
\text { vehicle status }\end{array}$ \\
\hline Scenario 1 & $\begin{array}{l}\text { The user view the vehicle status on the dashboard } \\
\text { page }\end{array}$ \\
\hline $\begin{array}{l}\text { Initial } \\
\text { condition }\end{array}$ & Vehicle status data has not appeared \\
\hline $\begin{array}{l}\text { Evaluation } \\
\text { steps }\end{array}$ & The user sees the dashboard page \\
\hline $\begin{array}{l}\text { Expected } \\
\text { results }\end{array}$ & $\begin{array}{l}\text { The application page can display the status of the } \\
\text { vehicle condition }\end{array}$ \\
\hline $\begin{array}{l}\text { Obtained } \\
\text { results }\end{array}$ & $\begin{array}{l}\text { The application page can display the status of the } \\
\text { vehicle condition }\end{array}$ \\
\hline Final condition & $\begin{array}{l}\text { The application page displays the status of the vehicle } \\
\text { condition }\end{array}$ \\
\hline Scenario 2 & $\begin{array}{l}\text { The user sees the log / history of the vehicle status } \\
\text { on the Device Log page }\end{array}$ \\
\hline $\begin{array}{l}\text { Initial } \\
\text { condition }\end{array}$ & The device log page is not open yet \\
\hline $\begin{array}{l}\text { Evaluation } \\
\text { steps }\end{array}$ & The user opens the device log page \\
\hline $\begin{array}{l}\text { Expected } \\
\text { results }\end{array}$ & $\begin{array}{l}\text { The application page can display a log of vehicle } \\
\text { condition status }\end{array}$ \\
\hline $\begin{array}{l}\text { Obtained } \\
\text { results }\end{array}$ & $\begin{array}{l}\text { The application page can display a log of vehicle } \\
\text { condition status }\end{array}$ \\
\hline Final condition & The application page displays the vehicle condition log \\
\hline
\end{tabular}

Based on the data in Table IV, V, VI, all test scenarios were successful and the program ran well. So that it can be concluded that the functionality of the application can work as expected. A summary of the evaluation results can be seen at TABLE VII.

TABLE VII. THE EVALUATION RESULT OF THE WHOLE SYSTEM FUNCTIONALITY

\begin{tabular}{|c|c|c|c|}
\hline code & Use case & Scenario & The Results \\
\hline \multirow{3}{*}{ UC-001 } & \multirow{3}{*}{$\begin{array}{l}\text { Stopped } \\
\text { vehicle } \\
\text { controlling }\end{array}$} & Scenario 1 & Succeed \\
\hline & & Scenario 2 & Succeed \\
\hline & & Scenario 3 & Succeed \\
\hline \multirow{2}{*}{ UC-002 } & \multirow{2}{*}{$\begin{array}{l}\text { Running } \\
\text { vehicle } \\
\text { controlling }\end{array}$} & Scenario 1 & Succeed \\
\hline & & Scenario 2 & Succeed \\
\hline \multirow[b]{2}{*}{ UC-003 } & \multirow{2}{*}{$\begin{array}{l}\text { Vehicle } \\
\text { status and } \\
\text { condition } \\
\text { monitoring }\end{array}$} & Scenario 1 & Succeed \\
\hline & & Scenario 2 & Succeed \\
\hline
\end{tabular}




\section{CONCLUSION}

From the results of the observations made during the design, implementation and evaluation process, it can be concluded that the functionality evaluation is succeed in all given scenario. This is indicated by the success of evaluation the system response to a given control and the web application is succeeding in monitoring and controlling the hardware device in a distance based on IoT.

\section{ACKNOWLEDGMENT}

This study was supported by the research grant for technology from Institut Teknologi Sepuluh Nopember Surabya, Indonesia.

\section{REFERENCES}

[1] Pratibha, L. Yadav, Sanjay S. Badhe, Santosh G. Bari, 2016, 'Study and Literature Survey for Safety Applications: Intelligent Transport System (ITS)', 5940 International Journal of Advanced Research in Computer and Communication Engineering Vol. 5.

[2] S. N. Paing, M. Z. Oo, M. Othman, and N. Funabiki " A Personal Use Vehicle Anti-Theft Tracking System Using IoT', International Journal of Computer and Software Engineering, Vol. 4 Issue 9, 2019, ISSN: 2456-4451.

[3] M. S. Uddin, M. M. Ahmed, J. B. Alam, and M. Islam, "Smart Antitheft Vehicle Tracking System for Bangladesh based on Internet of Things', 2017 4th International Conference on Advances in Electrical Engineering (ICAEE), Electronic ISSN: 2378-2692.

[4] H.V. Dadwani, R. B. Buktar "Vehicle Tracking and Antitheft System using Internet of Things", International Journal of Advances in Electronics and Computer Science, Vol. 4 Issue 10, Oktober 2017, pp. 69-72.

[5] S. S. Thakur, "Smart Car System using Sensor, GPS and GSM", International Journal of Current Engineering and Scientific Research (IJCESR), Vol. 5, Issue 1, 2018, 55-62.

[6] S. K. C. Varma, Poornesh, T. V. Harsha "Automatic Vehicle Accident Detection And Messaging System Using GPS and GSM Modems"International Journal of Scientific \& Engineering Research, Volume 4, Issue 8, August 2013.1937 ISSN 2229-5518

[7] Ruchita J. Shah, Anuradha P. Gharge, "GSM based Car Security System', Internasional Journal of Engineering and Innovative Technology (IJEIT), Vol. 2, Issue 4, October 2012.

[8] N. B. S. Ganapathy, S. Akash, R. A. Prabhu, T. Kirubakaran, and S. S. Kumar, "Anti-Theft Protection of Vehicle by GSM \& GPS with Fingerprint Verification', International Journal of Advanced Engineering, Management and Science (IJAEMS), Vol. 4, No. 4, April 2018, 251-254.

[9] Hu Jian-ming; Li Jie; Li Guang-Hui, "Automobile Anti-theft System Based on GSM and GPS Module," Intelligent Networks and Intelligent Systems (ICINIS), 2012 Fifth International Conference on , vol., no., pp.199,201, 1-3 Nov. 2012.

[10] P. Fleischer, A. Nelson, R. Sowah and A. Bremang, "Design and development of GPS/GSM based vehicle tracking and alert system for commercial inter-city buses," IEEE 4th International Conference on Adaptive Science \& Technology (ICAST), October 2012.

[11] S. P. Pingat, S. Rakhecha, R. Agrawal, S. Mhetre, and P. Raushan, "Real Time Smart Car Security System using Biometrics", International Journal of Innovative Technology and Exploring Engineering (IJITEE), Vol. 2, Issue. 4, March 2013, 166-168.

[12] S. Ajaz, M. Asim, M. Ozair, M. Ahmed, M. Siddiqui, Z. Mushtaq, "Autonomous Vehicle Monitoring \& Tracking System," SCONEST 2005, pp. $1-4$.

[13] Badan Pusat Statistik, 2014. [Online]. Available https://www.bappenas.go.id/files/data/Politik_Hukum_Pertahanan_d an_Keamanan/Statistik\%20Kriminal\%202014.pdf
[14] Arduino.cc, 'Arduino - $\quad$ Products', 2015. [Online].Available:http://arduino.cc/en/Main/Products. [Accessed: 22- Des- 2020].

[15] L. Louis, "Working Principle of Arduino and using it as A Tool for Study and Research', International Journal of Control, Automation, Communication and Systems (IJCACS), , Vol.1, No.2, April 2016, 21-29.

[16] K. S. Kaswan, S. P. Singh, S. Sagar, "Role Of Arduino In Real World Applications', International Journal of Scientific and Technology Research, Vol 9, Issue 1, January 2020, pp. 1113-1116.

[17] B.R. Swetha. D., Yuvasri., M. Karthiga, and S. Padma, "Density Based Traffic Control System Using Arduino Uno", SSRG International Journal of Industrial Engineering, 2017, pp. 5-7.

[18] howtomechatronics.com, 'Arduino Relay Tutorial-Control High Voltage Devices with Arduino',2020.[Online]. Available:https://howtomechatronics.com/tutorials/arduino/controlhigh-voltage-devices-arduino-relay-tutorial/. [Accessed: 18- Des2020].

[19] R. Amalia, H. Widiarto, and R. Soebiantoro, "Modifikasi Alat Kendali Air Conditioner Split di Laboratorium Maintenace Airfield Ground Lighting Sekolah Tinggi Penerbangan Indonesia," Jurnal Ilmiah Aviasi Langit Biru Vol. 13 No.1 Feb. 2020, Hal 71-78

[20] A. D. Vikhankar and R. P. Chaudhari. "Advanced Vehicle Security System with Theft Control and Accident Notification," International Journal of Innovative Research in Science, Engineering and Technology, Vol. 5, Issue 7, July 2016, pp. 12881-12894.

[21] R. Rahardi, D. Triyanto dan Suhard, "Perancangan Sistem Keamanan Sepeda Motor dengan Sensor Fingerprint, SMS Gateway, dan GPS Tracker berbasis Arduino ndengan Interface Website", Jurnal Coding, Sistem Komputer Untan, 2018, Vol. 6, Issue. 03, pp. 118-127.

[22] A. R. H. Martawireja, H. Supriyanto, "Penentuan Lintasan Pergerakan Quadcopter Berbasis GPS (Global Positioning System)', Jurnal Teknologi dan Rekayasa Manufaktur, Vol. 1, Issue 2, 2019, pp. $1-14$.

[23] T. Kalyani, S. Monika, B. Naresh and M. Vucha, “Accident Detection and Alert System', International Journal of Innovative Technology and Exploring Engineering (IJITEE), March, 2019 Vol. 8, Issue 4S2.

[24] Ardianto, belajarduino.com, 'SIM 800L GSM/GPRS Module to Arduino ', 2020.[Online]. Available: www.belajardunio.com. [Accessed: 19- Des- 2020].

[25] Faisal Alfaeru, Aries Boedi Setiawan, Nachrowi and Rachmat Hidayat S.,"Implementation of Accelerometer Sensor and GPS Module for Smart Bike Design", International Conference "Sustainable Development Goals 2030 Challenges and Its Solutions", 2017, 299-311.

[26] R. S. Abidin, D. Syauqy, R. Maulana, "Pengembangan Sistem Tracking Lokasi Low Power Sleep Pada Wearable Device', Jurnal Pengembangan Teknologi Informasi dan Ilmu Komputer, Vol. 2, No. 10, Oktober 2018, pp. 2569-3576

[27] T. P. Satya, F. Puspasari, H. Prisyanti and E. R. Meilani Saragih, "Perancangan dan Analisis Sistem Alat Ukur Arus Listrik menggunakan Sensor ACS712 berbasis Arduino Uno dengan standard Clampmeter', Jurnal SIMETRIS, Vol. 11, Issue, April 2020, pp. 3944

[28] Y. F. Luckyarno, S. S. Utami, Faridah , R. J. Yanti, “Desain Sistem Pemantau Konsumsi Energi untuk Rusunawa di Indonesia”, JNTETI, Vol. 8, No. 4, November 2019, pp. 379-384

[29] S. J. Sokop, D. J. Mamahit, and S. R. U. A. Sompie, "'Trainer Periferal Antarmuka Berbasis Mikrokontroler Arduino Uno,'” Journal Teknik Elektro dan Komputer vol.5 no.3 (2016), pp. 13-23.

[30] S. J. Sokop, D. J. Mamahit, and S. R. U. A. Sompie, "Aplikasi Sistem Rekam Medis di Puskesmas Kelurahan Gunung,', Jurnal Teknik Elektro dan Komputer, Volume 9, Nomor 1, September 2018, pp. 2231 